\title{
Lipoxygenase Isoenzymes: A Spectroscopic and Structural Characterization of Soybean Seed Enzymes
}

\author{
JAMES E. DRAHEIM,* RICHARD T. CARROLL, ${ }^{*}$ THOMAS B. MCNEMAR, ${ }^{*}$ \\ WILLIAM R. DUNHAM, † RICHARD H. SANDS, † AND MAX O. FUNK, JR. ${ }^{*, 1}$
}

\begin{abstract}
*Department of Chemistry, University of Toledo, 2801 West Bancroft Street, Toledo, Ohio 43006; and $†$ Biophysics Research Division, Institute for Science and Technology, University of Michigan, Ann Arbor, Michigan 48109
\end{abstract}

Received May 16, 1988, and in revised form October 17, 1988

\begin{abstract}
Applying recent develonments in protein purification techniques, a number of lipoxygenase isoenzymes have been isolated in satisfactory quantities for a detailed physical and structural characterization. Four seed isoenzymes from two soybean cultivars have been studied by peptide mapping, free thiol and iron content determinations, and Cterminal analysis as well as by uv-visible absorption and EPR spectroscopy. While differences between the type 1 enzyme and the other isoenzymes were readily detected using proteolytic peptide mapping, digestion with dilute hydrochloric acid and C-terminal analysis both revealed structural features which were similar in all of the isoenzymes. One clear difference between the lipoxygenases was in their free sulfhydryl group content. The $u v$-visible absorption spectrum of each native isoenzyme was consistent with expectations for the experimental aromatic amino acid content. All of the isoenzymes contained one non-heme iron atom per molecule of protein. The oxidation of each isoenzyme with product hydroperoxide resulted in the conversion of the iron from an EPR silent state into several forms with EPR signals characteristic of high spin iron(III). The EPR spectra of all isoenzymes were remarkably similar. A time course EPR and catalytic activity study revealed that the various EPR active states represent a complex equilibrium between iron atoms in different environments. The $\mathrm{pH}$ dependence for the EPR and absorption spectroscopy lends support to the hypothesis that acid/base chemistry represents an important aspect of lipoxygenase catalysis. (1989 Academic Press, Inc.
\end{abstract}

An important part of polyunsaturated fatty acid metabolism in plants and animals is associated with the lipoxygenasecatalyzed oxygenation reaction. In animals, the biosynthetic pathway to the leukotrienes and other biologically active eicosanoids is initiated by the lipoxygenasecatalyzed oxygenation of arachidonic acid (1). The enzyme has been known in higher plants for some time because of its readily detected catalytic activity and for its abundance, particularly in legume seeds (2). Physiological roles for the plant enzyme

\footnotetext{
${ }^{1}$ To whom correspondence should be addressed.
}

are less definite, but recent experiments indicate possible involvement in the biosynthesis of growth regulatory substances (3). Lipoxygenase isolated from soybean seeds has been extensively studied. It has been shown that the enzyme exists as a family of isoenzymes that have significantly different properties (4).

The soybean seed lipoxygenase isoenzymes can be separated on the basis of their net charge differences (5). The most striking functional difference between the various isoenzymes is in the $\mathrm{pH}$ range for optimal catalytic activity. Lipoxygenase 1 has catalytic activity over a wide range from $\mathrm{pH} 6$ to $10(6)$. By contrast, the other 
lipoxygenase isoenzymes are far less active at high $\mathrm{pH}$ than at neutral $\mathrm{pH}$. An additional difference is that the type 1 enzyme tends to be both regiospecific and stereospecific for the production of hydroperoxide product while the other isoenzymes are much less specific in their generation of product (7). A further distinction has been made among the isoenzymes on the basis of their ability to perform peroxidase chemistry as well as the lipoxygenase reaction (8). Finally, immunochemical experiments have been used to identify differences and similarities among the isoenzymes (9-11). In some experiments antibodies that are monospecific for a given isoenzyme have been reported. In other studies, cross-reactivity of antibodies to different isoenzymes has been found. In one interesting example, an antibody to lipoxygenase 2 which cross-reacted with the type 1 enzyme inhibited the former isoenzyme but not the latter (11). These experiments indicated that while the various isoenzymes may be structurally related, specific differences relevant to the dissimilarities in their catalytic activities can be detected.

While lipoxygenase 1 has been extensively characterized, the other isoenzymes are just beginning to receive attention as techniques for their efficient purification become available (5). All of the soybean seed lipoxygenase isoenzymes are large (95 $\mathrm{kDa}$ monomeric polypeptides (4). Also they all contain a single non-heme iron atom cofactor that is believed to play an important role in the catalytic process. In the native isoenzymes, the iron is present in an EPR silent high spin iron(II) form (12). Oxidation of the iron occurs upon incubation of the enzyme with an equimolar amount of the hydroperoxide product. This reaction is accompanied by the appearance of a characteristic EPR signal and changes in the lipoxygenase near-uv-visible $a b$ sorption spectrum and fluorescence emission spectrum $(2,13-15)$. To gain a greater understanding of the differences between the lipoxygenase isoenzymes that might account for their dissimilar catalytic activities, we have studied the properties of several of the soybean seed lipoxygenase isoenzymes.

\section{EXPERIMENTAL PROCEDURES}

Enzyme isolation and activity determination. Extraction of soybean seeds and purification of the lipoxygenase isoenzymes were performed as previously described $(5,12)$. The time required for isolation and purification was typically less than $48 \mathrm{~h}$. Catalytic activity was determined spectrophotometrically (234 $\mathrm{nm})$ at $\mathrm{pH} 9.0$ in $0.1 \mathrm{M}$ Tris or borate buffer $(3.00 \mathrm{ml}$ total volume) using $0.02 \%$ linoleic acid (v/v) at $25.0^{\circ} \mathrm{C}$ and at $\mathrm{pH} 7.0$ in $0.14 \mathrm{M}$ sodium phosphate or Tris buffer $(1.00 \mathrm{ml}$ total volume $)$ using $0.28 \%$ linoleic acid $(\mathrm{v} / \mathrm{v})$ and $0.10 \%$ Tween $20(\mathrm{v} / \mathrm{v})$ at $25.0^{\circ} \mathrm{C}$. The maximum slope or linear portion of the progress curve was used as an estimate of the initial velocity of the reaction. Typically the type 1 (P1 and V1) enzymes displayed 1,000,000 units/mg protein at $\mathrm{pH} 9$ and the other isoenzymes (P4 and V2) displayed 30,000 units/ $\mathrm{mg}$ protein at $\mathrm{pH} 7$. One unit in each case refers to an increase of 0.001 absorbance units at $234 \mathrm{~nm} / \mathrm{min}$.

Peptide mapping. The procedure of Cleveland $e t$ al. (16) was used incorporating the following modifications. Samples of each isoenzyme $\left(1.5 \mathrm{mg} \mathrm{ml}^{-1}, 0.1 \mathrm{M}\right.$ Tris, $\mathrm{pH} 7.0,0.05 \% \mathrm{SDS}^{2}$ ) were incubated at room temperature for $30 \mathrm{~min}$. To these solutions aliquots of either Staphylococcus aureus V8 protease or $\alpha$-chymotrypsin ( $0.03 \mathrm{mg} \mathrm{ml}^{-1}$ ) were added. Digestion was allowed to proceed for $30 \mathrm{~min}$ at ambient temperature. The solutions were then combined with sample preparation buffer for SDS-PAGE and heated at $100^{\circ} \mathrm{C}$ for $2 \mathrm{~min}$. Partial acid hydrolysis was performed by combining $0.10 \mathrm{ml}$ of $0.022 \mathrm{M} \mathrm{HCl}$ with 0.05 $\mathrm{ml}$ of each isoenzyme $\left(12 \mathrm{mg} \mathrm{ml} \mathrm{m}^{-1}\right)$. Samples were heated in glass tubes at $100^{\circ} \mathrm{C}$ for $5 \mathrm{~min}$, cooled on ice, and then diluted with sample prep buffer for SDSPAGE. Electrophoresis was performed using the buffer system described by Laemmli (17). Gels were stained with Coomassie brilliant blue. The molecular weight standards were $1,97,000 ; 2,66,000 ; 3,43,000 ; 4$, 31,$000 ; 5,20,000$; and $6,14,600$.

Other chemical determinations. The iron content of each isoenzyme was obtained by flame atomization atomic absorption spectrometry. Protein samples ranging in concentration between 3 and $8 \mathrm{mg} \mathrm{ml}^{-1}$ were analyzed using an Instrumentation Laboratory Model Video 11 spectrophotometer and were compared to standard iron solutions ranging in concentration from 0.1 to $5.0 \mu \mathrm{g} \mathrm{ml}^{-1}$.

Free sulfhydryl groups were determined using Ellman's method (18) for each isoenzyme after denaturation in $2 \%$ SDS, 0.1 m sodium phosphate, $\mathrm{pH} 8.0$.

\footnotetext{
${ }^{2}$ Abbreviations used: SDS, sodium dodecyl sulfate; PAGE, polyacrylamide gel electrophoresis.
} 
Carboxyl terminal sequence analysis $(19,20)$ was performed on $60 \mathrm{nmol}$ of each isoenzyme. The digestion solution contained in addition to the enzyme, 0.1 M sodium phosphate buffer at $\mathrm{pH} 7,0.1 \% \mathrm{SDS}$, and 60 nmol of norleucine as an internal standard in a final volume of $6.5 \mathrm{ml}$. The digestion solution was heated in boiling water for $2 \mathrm{~min}$ and then placed in a water bath at $37^{\circ} \mathrm{C}$ for $30 \mathrm{~min}$. An initial aliquot was removed and diluted with an equal volume of acetone. The digestion was initiated by the addition of carboxypeptidase $Y$ at a mole ratio of peptidase to lipoxygenase of 1 to 1000 . Aliquots were removed at various time intervals and the digestion was quenched by the addition of acetone. The samples were centrifuged and the supernatant was removed and dried. The dried samples were then subjected to amino acid analysis using a Beckman 6300 amino acid analyzer.

Amino acid analyses of the lipoxygenases were performed following hydrolysis in $6 \mathrm{~N} \mathrm{HCl}$ at $110^{\circ} \mathrm{C}$ for 24,48 , and $72 \mathrm{~h}$.

Ultraviolet-visible absorption. Absorption spectra were measured using a Varian 100 DMS dual beam spectrophotometer. All absorption spectra were corrected for solvent baseline. Sample temperature was ambient. Fresh pure lipoxygenase isoenzyme was suspended in $100 \mathrm{~mm}$ Tris buffer ( $\mathrm{pH} 7$ and 9 ) such that the final protein concentration was $1-2 \mu \mathrm{M}$. Protein concentrations were determined using the Bradford assay (21). The enzyme was oxidized by incubation with 13 -hydroperoxy $-9(Z), 11(E)$-octadecadienoic acid (22) for at least 30 min on ice. Special care was taken to ensure that the protein concentrations of the native and oxidized proteins were identical for each isoenzyme studied.

$E P R$ spectroscopy. The $9 \mathrm{GHz}$ measurements were performed using a Varian Century Line spectrometer equipped with a homemade, gas phase liquid helium transfer line and quartz dewar cavity insert. Temperature measurements were made using a $0.1 \mathrm{~W}$ Allen Bradley carbon composition resistor calibrated at liquid helium, liquid nitrogen, and ambient temperatures (23). Frequency measurements were determined continuously using a Hewlett-Packard 5340A frequency counter. Field calibration $(>100 \mathrm{~m}$ T) was accomplished using a Systron-Donner Model 3193 digital NMR gaussmeter. All spectra were obtained at $25^{\circ} \mathrm{K}$ using microwave powers that avoided modulation broadening (typically $5 \mathrm{~mW}$ power and $1 \mathrm{mT}$ modulation amplitude). Scan time for each measurement was 4 min using a time constant of $0.128 \mathrm{~s}$. The spectra were generated as difference spectra (sample minus buffer control) and were normalized to represent the same enzyme concentration within each figure. Oxidation with product was carried out at $100 \mu \mathrm{M}$ enzyme followed by concentration (Centricon 30 ) to a final volume of $0.25 \mathrm{ml}$ for each EPR sample.

\section{RESULTS}

There are differences in the number and type of lipoxygenase isoenzymes in the seeds of different soybean cultivars. The present study is concerned with the isoenzymes found in two cultivars (Vickery and Provar). Both contain the type 1 enzyme and at least one other form of lipoxygenase (5). The purification of lipoxygenase by chromatofocusing leads to the resolution of at least four isoenzymes $(5,6,24)$. Since the original Theorell enzyme elutes last and has traditionally been referred to as type 1 , the numbering system we have adopted to keep track of the isoenzymes reflects the reverse order of their elution from the chromatofocusing column. We have chosen to concentrate on two isoenzymes that appear to be the same in each cultivar, the type 1 enzymes (V1 and P1), and two which are different both from each other and from the type 1 enzyme on the basis of net charge properties (V2 and P4). Based upon net charge differences and the nature of the catalytic activity a reasonable correlation can be made between the lipoxygenases reported on here and those investigated previously at other laboratories (vide infra).

Protein chemistry. Enzymatic and chemical methods have been applied to the comparison of the primary structure of the various lipoxygenases. Typical results for two proteolytic digestions as well as for mild acid hydrolysis are provided in Fig. 1. For both chymotrypsin and the protease from $S$. aureus strain V8, digestion results in a distinctive pattern of peptides. The isoenzymes can be grouped into two categories. The type 1 enzymes from both cultivars give identical results which are significantly different from those obtained from V2 and P4. Interestingly, the patterns obtained for V2 and $\mathrm{P} 4$ were indistinguishable even though these isocnzymes are clearly differentiated chromatographically. Mild acid hydrolysis, which is selective for the cleavage of the peptide bond between aspartic acid and proline residues, produced fragments which were quite similar for all of the isoenzymes. Because the $\mathrm{N}$-terminal amino acid of lipoxygenase has been reported to be blocked with respect to determination using Edman chemistry (25), the determination of the C-terminal residues was investigated. The treatment 


\section{Chymotrypsin}

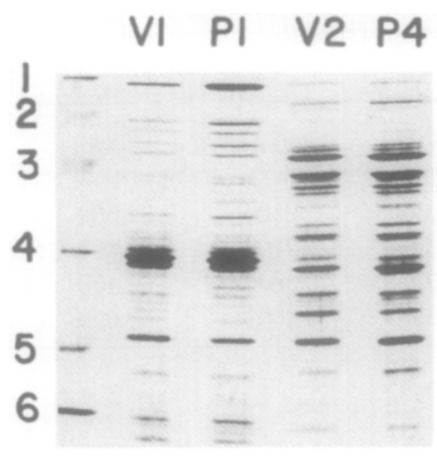

$\mathrm{HCl}$

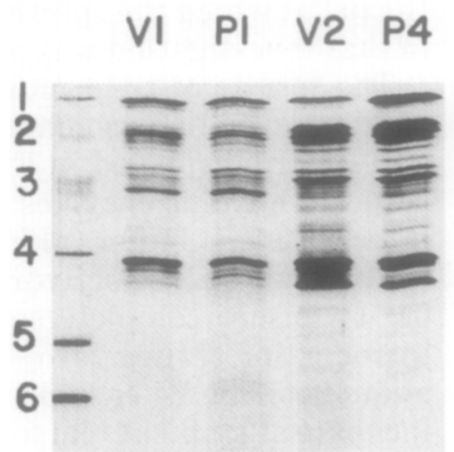

\section{V8 Protease}

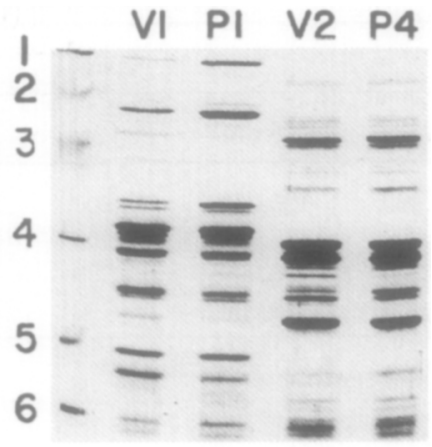

Control

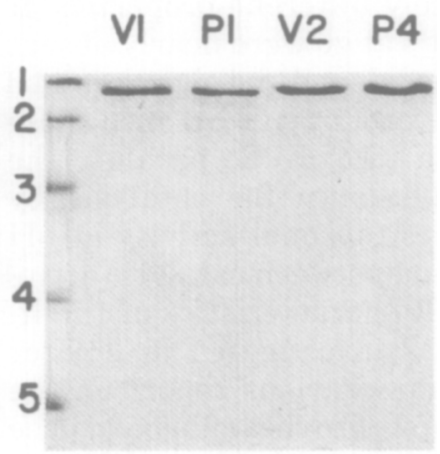

FIG. 1. SDS-polyacrylamide gel electrophoresis of the lipoxygenase isoenzymes prior (control) and subsequent to proteolytic digestion with $\alpha$-chymotrypsin and V8 protease, and mild acid hydrolysis with $\mathrm{HCl}$.

of each isoenzyme with carboxypeptidase $\mathrm{Y}$ resulted in a similar rapid release of 2 mol each of the amino acids serine and isoleucine. Attempts to increase the selectivity of the digestion to determine the exact order of the amino acids by reducing the enzyme concentration or by lowering the temperature were not successful. The four lipoxygenase isoenzymes were also characterized on the basis of their iron and free sulfhydryl contents. The values for the iron content (g-atom/mol) were 0.95 (V1), 0.99 (P1), 0.92 (V2), and 0.98 (P4). The numbers of free sulfhydryl groups per protein molecule for the various lipoxygenases were 4 (V1), 4 (P1), 6 (V2), and 7 (P4).

Spectroscopy. Near-uv-visible absorption spectra were recorded for both the native and product oxidized forms of the four isoenzymes used in this study. The data for selected wavelengths are presented in Table I.

The EPR spectroscopic properties of the various isoenzymes treated with equivalent quantities of the product hydroperoxide were examined at $\mathrm{pH} 7$ and 9 (Figs. 2 and 3). The spectra for two versions of lipoxygenase 1 (P1 and V1) closely reproduced previously published results from several laboratories. The other isoenzymes (V2 and P4) displayed a strikingly different $\mathrm{pH}$ dependence for their EPR spectra when compared to the type 1 enzyme. Where the spectra for lipoxygenase 1 had less rhombic character and more of the axial component at $\mathrm{pH} 9$ versus $\mathrm{pH} 7$ as has been reported previously (26), spectra for the other isoenzymes, which were very 
TABLE I

LIPOXYGENASE EXTINCTION COEFFICIENTS $^{a}$

\begin{tabular}{|c|c|c|c|c|c|c|c|c|}
\hline \multirow[b]{2}{*}{ Isoenzyme } & \multicolumn{5}{|c|}{ Native } & \multicolumn{3}{|c|}{ Oxidized } \\
\hline & $247 \mathrm{~nm}$ & $278 \mathrm{~nm}$ & $289 \mathrm{~nm}$ & $295 \mathrm{~nm}$ & $330 \mathrm{~nm}$ & $247 \mathrm{~nm}$ & $295 \mathrm{~nm}$ & $330 \mathrm{~nm}$ \\
\hline P1 & 47,300 & 120,000 & 78,900 & 30,200 & 2100 & 52,500 & 31,500 & 5800 \\
\hline $\mathbf{P} 4$ & 45,200 & 118,000 & 78,900 & 30,800 & 2100 & 62,400 & 37,400 & 6900 \\
\hline V1 & 57,200 & 125,000 & 87,200 & 33,600 & 2800 & 62,400 & 34,500 & 4200 \\
\hline V2 & 51,400 & 119,000 & 82,700 & 35,400 & 2500 & 60,000 & 37,400 & 4400 \\
\hline
\end{tabular}

${ }^{a}$ Liters per mole per centimeter.

similar to lipoxygenase 1 at $\mathrm{pH} 7$, displayed completely different properties at $\mathrm{pH}$ 9. The signals at $\mathrm{g} 6$ were nearly absent in the $\mathrm{pH} 9$ spectra, and the signal at $\mathrm{g} 4.3$ was much more prominent. Because these observations in the EPR parallel the known $\mathrm{pH}$ dependence for catalysis by these isoenzymes (optimal activity at $\mathrm{pH}$ 7), the correlation between catalytic activity and the EPR characteristics of the lipoxygenases was investigated in greater detail. In the one previous report on the EPR spectroscopy of soybean lipoxygenase 2 (27) the spectra were dominated by the g4.3 signal. Comparison with the previous

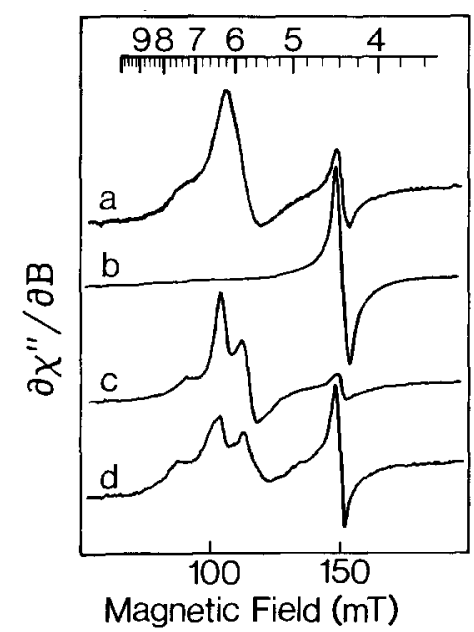

FIG. 2. EPR spectra for the Provar lipoxygenase isoenzymes $(419 \mu \mathrm{M}) . \mathrm{P} 1, \mathrm{pH} 9$ (curve a); $\mathrm{P} 4, \mathrm{pH} 9$ (curve b); $\mathrm{P} 1$, pH 7 (curve c); $\mathrm{P} 4, \mathrm{pH} 7$ (curve d). Frequency $9.227 \mathrm{GHz}$. results in this case is complicated because the $\mathrm{pH}$ at which the spectra were obtained in that investigation was not reported.

The results of time course EPR experiments on the lipoxygenase isoenzymes $\mathrm{P} 4$ and P1 are displayed in Fig. 4 and Fig. 5, respectively. The enzymes were suspended in $200 \mathrm{~mm}$ Tris buffer $(\mathrm{pH} 7$ and $\mathrm{pH} \mathrm{9})$ and oxidized with 1.1 eq of hydroperoxide product to ensure complete conversion. After introduction of the hydroperoxide product, aliquots of the $\mathrm{P} 4$ enzyme were allowed to incubate at ambient temperature for $5 \mathrm{~min}$ and 1 and $2 \mathrm{~h}$ prior to freezing in EPR tubes. The catalytic activity of each aliquot

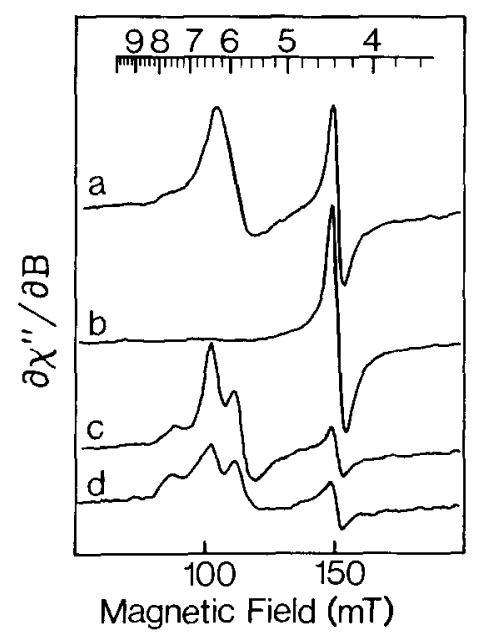

FIG. 3. EPR spectra of the Vickery lipoxygenase isoenzymes $(428 \mu \mathrm{M}$ ). V1, pH 9 (curve a); V2, pH 9 (curve b); V1, pH 7 (curve c); V2, pH 7 (curve d). Frequency $9.225 \mathrm{GHz}$. 


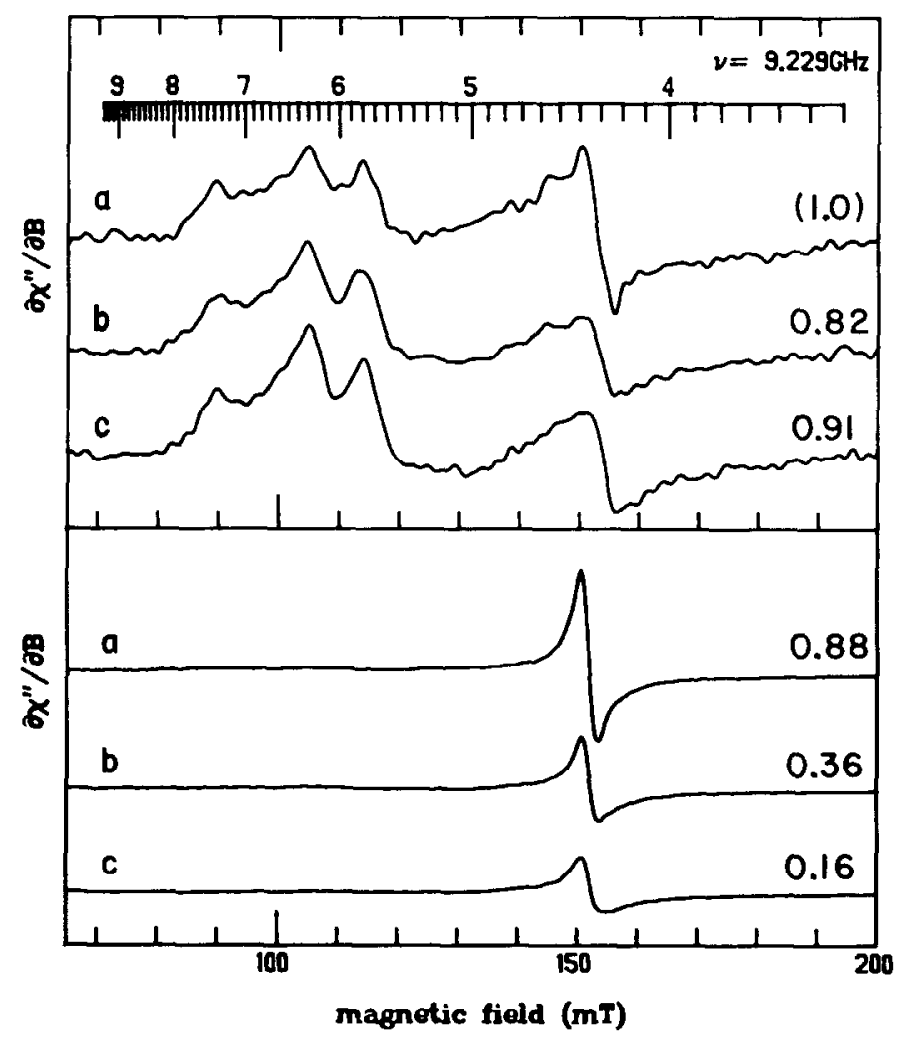

FIG. 4. Time course EPR spectra of the P4 isoenzyme ( $200 \mu \mathrm{M})$ in $200 \mathrm{mM}$ Tris subsequent to oxidation with $1.1 \mathrm{eq}$ hydroperoxide product after $t=5 \mathrm{~min}$ (curve a), $t=1 \mathrm{~h}$ (curve b), and $t=2 \mathrm{~h}$ (curve c). Incubation temperature ambient. Upper panel, $\mathrm{pH}$ 7. Lower panel, $\mathrm{pH} 9$. The relative catalytic activity of each EPR sample is labeled on each spectrum. The catalytic activities were normalized to that of the $\mathrm{pH} 7, t=5 \mathrm{~min}$ EPR sample.

was also measured immediately after each incubation period ( $\mathrm{pH} 7$ reaction mixture, "type 2" kinetics). A similar procedure was followed for the P1 isoenzyme with the exception that the incubation of aliquots was carried out at $50^{\circ} \mathrm{C}$.

In $\mathrm{pH} 7$ buffer at ambient temperature the P4 isoenzyme exhibited EPR spectra and catalytic activity at $\mathrm{pH} 7$ which were both relatively stable over the 2 -h time period. By contrast, in pH 9 buffer the $\mathrm{P} 4$ enzyme exhibited a loss in catalytic activity, measured at $\mathrm{pH} 7$, with time concomitant with a loss in EPR intensity at g4.3 (linear correlation, $r^{2}=0.999$ ). In $\mathrm{pH} 9$ buffer the g6 EPR signal was nearly abolished. The complete loss of EPR signal with time at $\mathrm{pH} 9$ is due either to the loss of iron from the enzyme or to the association of the spin systems from two enzyme molecules, i.e., dimerization. In fact the 44.3 signal represents only a fraction of the total iron in the sample. The concentration of the species responsible for each signal can be approximated from the total integrated intensity (28). The g4.3 signal for the P4 isoenzyme oxidized at pII 9 represents roughly $65 \mu \mathrm{M}$ iron(III) of the $200 \mu \mathrm{M} \mathrm{P} 4$ solution or $33 \%$ of the enzyme. By contrast, the signal at $\mathrm{g} 6$ for $\mathrm{P} 4$ oxidized at $\mathrm{pH} 7$ and incubated for 1 $\mathrm{h}$ integrated as $121 \mu \mathrm{M}$ iron(III) or $61 \%$ of the $200 \mu \mathrm{M}$ enzyme solution. While the $\mathrm{g} 4.3$ signals integrate smoothly because of their sharpness, the broad g6 signals are much more difficult to determine accurately. The integrations for the g6 signals were truncated very conservatively such that the values reported represent extreme 


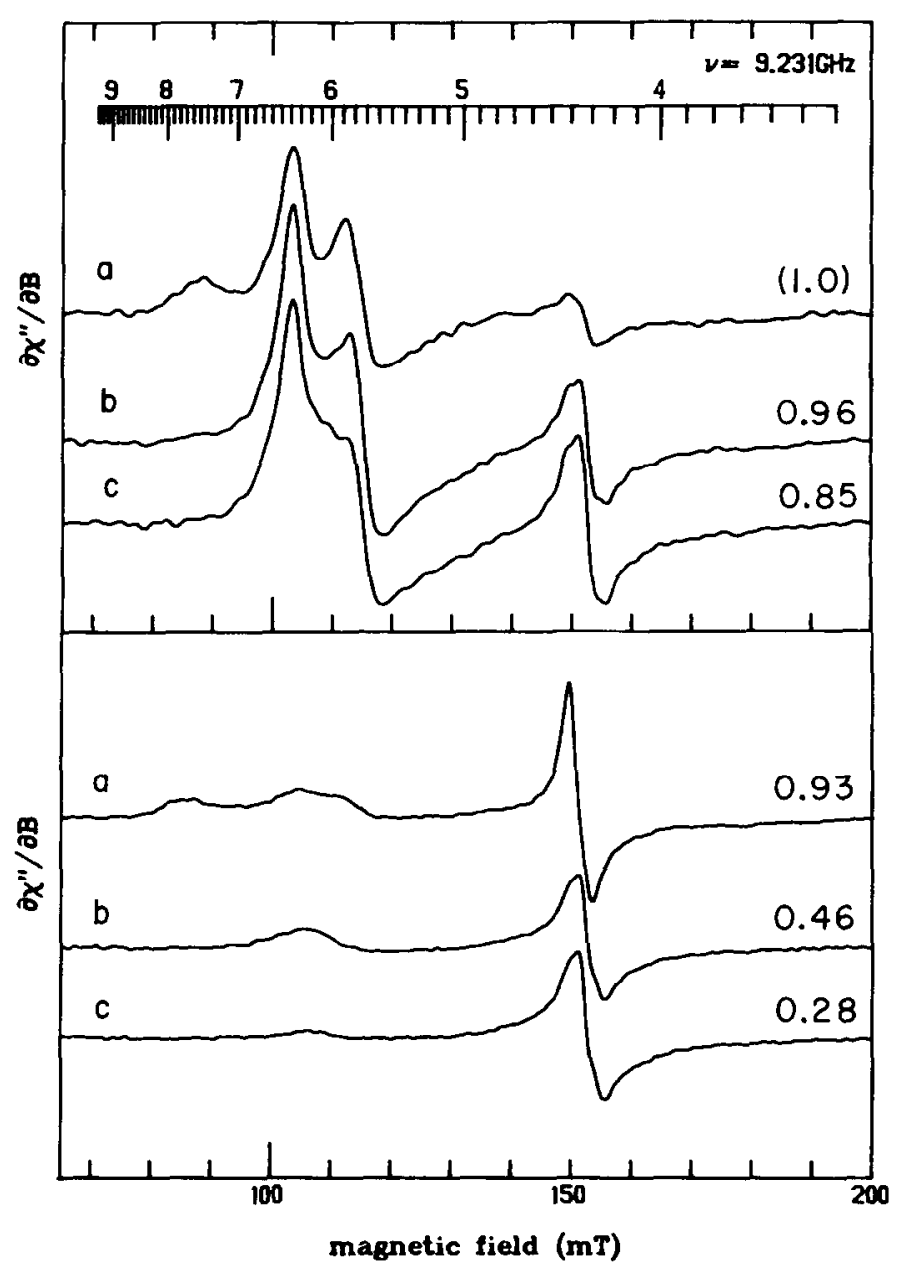

FIG. 5. Time course EPR spectra of the P1 isoenzyme $(200 \mu \mathrm{M})$ in $200 \mathrm{~mm}$ Tris subsequent to oxidation with $1.1 \mathrm{eq}$ hydroperoxide product after $t=5 \mathrm{~min}$ (curve a), $t=1 \mathrm{~h}$ (curve b), and $t=2 \mathrm{~h}$ (curve c). Incubation temperature $50^{\circ} \mathrm{C}$. Upper panel, $\mathrm{pH}$ 7. Lower panel, $\mathrm{pH}$ 9. The relative catalytic activity of each EPR sample is labeled on each spectrum. The catalytic activities were normalized to that of the $\mathrm{pH} 7, t=5 \mathrm{~min}$ EPR sample.

minimum concentrations for the observed spin. Therefore the signal at $\mathrm{g} 6$ in the example represents no less than $121 \mu \mathrm{M}$ high spin iron(III). The fact that the sample of the isoenzyme incubated for $5 \mathrm{~min}$ at $\mathrm{pH} 9$ had little g6 EPR signal intensity and yet retained nearly $90 \%$ of its catalytic activity at $\mathrm{pH} 7$ suggested that the effect of $\mathrm{pH}$ on the spectroscopic properties might also be reversible. When the $\mathrm{P} 4$ isoenzyme was first oxidized at $\mathrm{pH} 9$ then combined with buffer to bring the $\mathrm{pH}$ of the sample down to 7 , and finally concentrated $(300 \mu \mathrm{M})$ for
EPR determination, a g6 signal accounting for no less than $180 \mu \mathrm{M}$ iron(III), or $60 \%$ of the enzyme, was observed (data not shown). By contrast, the g4.3 signal in this sample accounted for $12 \mu \mathrm{M}$ iron(III), or $4 \%$ of the enzyme concentration. The sample oxidized at $\mathrm{pH} 9$ for EPR analysis at $\mathrm{pH} 7$ displayed $71 \%$ of control activity.

The EPR spectrum and $\mathrm{pH} 7$ catalytic activity of $\mathrm{P} 1$ incubated at $\mathrm{pH} 7$ were remarkably stable at $50^{\circ} \mathrm{C}$. In $\mathrm{pH} 9$ buffer at $50^{\circ} \mathrm{C}$ the $\mathrm{P} 1$ isoenzyme exhibited a loss in catalytic activity with time concomitant 
with a loss in EPR intensity at $\mathrm{g} 6$ (linear correlation, $r^{2}=0.999$ ). Interestingly, the rhombic component of the g6 signal appears to vanish before the axial component. There was also a loss of EPR intensity at $\mathrm{g} 4.3$ for the $\mathrm{pH} 9$ incubations although the correlation $\left(r^{2}=0.877\right)$ was not as significant as for the $\mathrm{g} 6$ signal.

\section{DISCUSSION}

The differences in the catalytic activities of the lipoxygenase isoenzymes are reflected in the structural properties of the proteins as revealed by peptide mapping experiments. Enzymatic digestion patterns for the type 1 enzyme were the same irrespective of the cultivar source and differed significantly from those obtained for the other isoenzymes studied (V2 and $\mathrm{P} 4)$. The results indicate that the isoenzymes can be loosely grouped into two categories on the basis of these structural characteristics: the type 1 enzyme and the others. However, the differences between the type 1 lipoxygenases and the other isoenzymes may be due to limited differences in primary structure, i.e., substitution of key amino acid residues, rather than global differences in sequence. While the enzymatic digestions of the various lipoxygenase isoenzymes result in significantly different fragments, the treatment with mild acid leads to quite similar patterns of peptides for all of the isoenzymes. A further indication of the similarity in the primary structure of the isoenzymes was the observation that the same amino acids were released from the $\mathrm{C}$-terminal of each protein upon carboxypeptidase $\mathrm{Y}$ digestion. The complete primary structure of lipoxygenase 1 as deduced from the corresponding cDNA sequence was reported recently (29). The C-terminal amino acids were found to be Ser-Ile-Ser-Ile. The results of the carboxypeptidase $Y$ digestion were therefore in agreement with the reported sequence and indicated that this structural property is probably shared by all of the lipoxygenase isoenzymes. Very recently the primary sequence of lipoxygenase 2 from soybeans was reported (30). The same amino acid sequence was found for the C-terminal of this enzyme as for lipoxygenase 1 . The findings reported on here therefore confirm and extend the discoveries from the primary structure determinations.

A number of reports have described the resolution of multiple lipoxygenase isoenzymes. The type 1 enzyme with its distinctive optimum for catalytic activity around pH 9 is readily identified as the same in all investigations. The first lipoxygenase to elute from the chromatofocusing column (P4) in our experiments has the same $\mathrm{p} I$ and kinetic properties for catalysis as the lipoxygenase 2 described by Christopher et al. (6). The P4 isoenzyme is also presumably the same as the lipoxygenase $2 a$ of Feiters et al. (24). The two isoenzymes eluting between $\mathrm{P} 4$ and V2 (present in each cultivar of seed to varying degrees) in the chromatofocusing experiment are probably the same as the lipoxygenase $3 \mathrm{a}$ and $3 \mathrm{~b}$ of Christopher et al. (6). These proteins were neither sufficiently resolved nor adequately stable for us to include in this study as discrete isoenzymes. The other isoenzyme included in this investigation, $\mathrm{V} 2$, has a unique $\mathrm{p} I$ for a lipoxygenase, migrating between the lipoxygenase 3's and the type 1 enzyme in analytical isoelectric focusing experiments.

The free sulfhydryl content for the various lipoxygenase isoenzymes has been reported periodically. For example, values ranging from 3 to 7 residues per molecule has been obtained for lipoxygenase 1 (31). Our results for the type 1 enzymes were in agreement with the value found in the deduced amino acid sequence of the entire protein which indicated that 4 residues were encoded by the cDNA analyzed (29). The present study also revealed that the number of free sulfhydryl groups present in the other isoenzymes was significantly larger than that for the type 1 enzyme. The observation represents one specific difference between the structures of the various isoenzymes.

For an iron containing protein, lipoxygenase has rather uninformative spectroscopic properties in the near-UV and visible regions. The native isoenzymes are nearly colorless even at very high concen- 
trations while, solutions of product oxidized enzyme exhibit a pale yellow color. This color is due to an increased absorbance at longer wavelengths upon oxidation. It must be noted that there is no more than a weak broad shoulder in the absorption spectrum ca. $330 \mathrm{~nm}$ characterizing this transition. The increase in absorbance in this region has been interpreted as arising from new charge transfer transitions resulting from the formation of the iron(III) moiety. The increases in absorbance observed at 245 and $295 \mathrm{~nm}$ upon product induced oxidation could also be due to new charge transfer transitions involving the iron atom.

Additional or alternate explanations for the spectral changes observed upon oxidation should also be considered. For example, the increases in absorbance at 247 and $295 \mathrm{~nm}$ for each isoenzyme upon oxidation were highly reminiscent of the changes in absorbance observed upon ionization of ty- rosine in proteins. The difference absorption spectrum of tyrosinate minus tyrosine in aqueous solution exhibits positive peaks at 243 and $296 \mathrm{~nm}$. Changes in extinction of 10,000 liters $\mathrm{mol}^{-1} \mathrm{~cm}^{-1}$ at $245 \mathrm{~nm}$ and 2300 liters $\mathrm{mol}^{-1} \mathrm{~cm}^{-1}$ at $295 \mathrm{~nm}$ were observed in the tyrosinate-tyrosine difference spectrum (32). The absorbance changes in the near-uv observed upon product induced oxidation of native lipoxygenase isoenzymes corresponded to the ionization of roughly one tyrosine per molecule of protein. The possibility that a tyrosine to tyrosinate conversion accompanied the product induced oxidation of the lipoxygenase isoenzymes has potentially interesting consequences. It has been concluded that the interaction of lipoxygenase 1 with product was a one electron reduction of the hydroperoxide (33). In this case, the reaction would be expected to produce an equivalent amount of base as shown in the equation:

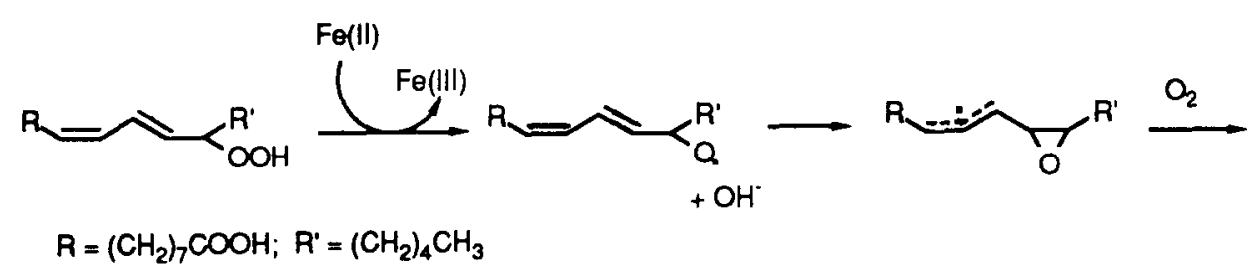

The alkoxy radical is thought to undergo internal cyclization under these conditions followed by reaction with molecular oxygen (34) leading to a nonabsorbing product. It is possible, in light of the observed spectral changes, that the enzyme takes advantage of a nearby tyrosine residue to neutralize the base that is formed as a consequence of this reaction. This further implies that the reaction between the enzyme and product lowers the $\mathrm{p} K_{a}$ for the ionizable group, since simply raising the $\mathrm{pH}$ does not have this effect. The presence of a catalytically important basic residue in the active site during the oxygenation reaction has been proposed (35).

An estimate of the tryptophan content was made for each isoenzyme using a variation of the method of Edelhoch (36). The extinction of both the tyrosine and tryptophan residues in a protein is dependent

upon environmental hydrophobicity. It was assumed that for a large protein such as lipoxygenase, the average environmental hydrophobicity of its tyrosine residues is similar to that for its tryptophan residues. Thus an analysis which is self consistent with respect to the amino acid content would be valuable. Using Edelhoch's equation,

$$
\begin{array}{r}
M(\operatorname{Trp})+\left(0.322 \times \text { Extinction }_{288}-0.0969\right. \\
\left.\times \text { Extinction }_{280}\right) \times 10^{-3},
\end{array}
$$

the calculated tryptophan content was ca. 15 for the P1 isoenzyme and 16 for the other isoenzymes. The amino acid analyses of these isoenzymes indicated a tyrosine content of 33 (P1), 28 (P4), 33 (V1), and 31 (V2). Using an extinction coefficient at 278 $\mathrm{nm}$ of 1400 liters $\mathrm{mol}^{-1} \mathrm{~cm}^{-1}$ for tyrosine and 5000 liters $\mathrm{mol}^{-1} \mathrm{~cm}^{-1}$ for tryptophan, 
the calculated peak extinction coefficients for the isoenzymes were 121,000 (P1), 119,200 (P4), 126,200 (V1), and 123,400 (V2). These calculated values are close to the measured values of 120,000 (P1), 118,000 (P4), 125,000 (V1), and 119,000 (V2). According to the cDNA sequence analysis there are 39 tyrosines and 14 tryptophanes in lipoxygenase 1 (29). The calculated peak extinction coefficient at $278 \mathrm{~nm}$ for this amino acid content would then be 124,600 liters $\mathrm{mol}^{-1} \mathrm{~cm}^{-1}$ which is also consistent with the present results. The concern for correlating the absorbance characteristics to the amino acid composition arose because the peak extinction values were significantly lower than the literature values for lipoxygenase $1,174,000$ or 152,000 liters $\mathrm{mol}^{-1} \mathrm{~cm}^{-1}(31,37)$. Only freshly prepared samples of lipoxygenase were used in the present study. We observed higher extinction values in samples that were stored for extended periods at low concentration (less than $5 \mu \mathrm{M}$ ).

The EPR spectra of product oxidized lipoxygenase isoenzymes exhibited an interesting $\mathrm{pH}$ dependence. At $\mathrm{pH} 7$ all of the isoenzymes have the same distinctive EPR spectrum, which implies a high degree of similarity in the structure of the iron binding sites in the proteins. At $\mathrm{pH} 7$ the EPR spectra exhibited signals at both g6 and $\mathrm{g} 4.3$, while at $\mathrm{pH} 9$ only the type 1 enzymes retained their g6 signals to a significant extent. A somewhat analogous situation in the EPR spectroscopy of the non-heme iron containing enzyme phenylalanine hydroxylase was reported recently $(38,39)$. EPR signals for phenylalanine hydroxylase were observed at both $\mathrm{g} 6$ and $\mathrm{g} 4.3$. In that example catalytic activity was inversely correlated with the EPR signals at g4.3 found in different preparations of the enzyme. Consequently it was concluded that only the g6 EPR signal was representative of iron(III) in the active enzyme.

On the basis of our observations, the same basic conclusion is reached, but a different explanation is necessary for the EPR spectroscopy of lipoxygenase. At $\mathrm{pH}$ 9 the product oxidized $\mathrm{P} 4$ isoenzyme exhibited a spectrum with no g6 signal. However, at least initially this enzyme was still catalytically active to an extent comparable to native $\mathrm{P} 4$ at $\mathrm{pH} 7$. Moreover, there was a linear relationship between the loss of catalytic activity and loss of the only signal in the EPR spectrum (g4.3) in samples of $\mathrm{P} 4$ incubated at $\mathrm{pH} 9$. This implies that the iron responsible for the $\mathrm{g} 4.3$ signal is not due exclusively to a contaminant, but is also due in part to the iron cofactor existing in an unstable environment. Further, since the integrated intensity of the g4.3 signal accounted for only about $33 \%$ of the iron known to be present in the sample of $\mathrm{P} 4$ incubated at $\mathrm{pH} 9$ for $5 \mathrm{~min}$, an EPR silent iron form of the enzyme appears also to be present. Both forms of the enzyme present at $\mathrm{pH} 9$ recovered their ability to catalyze peroxidation when the $\mathrm{pH}$ was reduced because the activity was comparable $(88 \%)$ to the enzyme incubated only at $\mathrm{pH}$ 7. Further, samples oxidized at $\mathrm{pH} 9$ but subsequently observed in the EPR at $\mathrm{pH} 7 \mathrm{had}$ the g6 signal. The overall conclusion is that the catalytic activity correlates best with the observation of the g6 signal in samples of all of the product oxidized isoenzymes. The results also indicated a reversible $\mathrm{pH}$-dependent change in the EPR spectrum and catalytic activity of the $\mathrm{P} 4$ isoenzyme. Therefore the observation of a 94.3 signal in the EPR was not necessarily indicative of inactive enzyme in contrast to the results for phenylalanine hydroxylase.

From these observations it is clear that the various lipoxygenase isoenzymes share many common structural and chemical elements. Further studies can now be focused on identifying the structural differences between the isoenzymes that may be responsible for the characteristic features of their physical properties and catalytic activities.

\section{ACKNOWLEDGMENTS}

This research was supported financially by the $\mathrm{Na}$ tional Institutes of Health and the National Science Foundation. Max O. Funk, Jr. is the recipient of a Research Career Development Award from the National Institutes of Health. We are grateful to Y. Nakagawa for performing amino acid analyses. 


\section{REFERENCES}

1. Dahlen, S. E., Lindgren, J. A., Rouzer, C. A., Serhan, C. N., and Samuelsson, B. (1987) Science 237, 1171-1176.

2. Finnazi-Agro, A., Avigliano, L., Veldink, G. A., VliegenthaRT, J. F. G., AND Boldingh, J. (1973) Biochim. Biophys. Acla 326, 462-470.

3. Vick, B. A., ANd Zimmerman, D. C. (1984) Plant Physiol. 75, 458-461.

4. Axelrod, B., Cheeshruugh, T. M., and Laasko, S. (1981) in Methods in Enzymology (Lowenstein, J. M., Ed.), Vol. 71, pp. 441-451, Academic Press, San Diego.

5. Funk, M. O., Whitney, M. A., Hausknecht, E. C., AND O'BRIEN, E. M. (1985) Anal. Biochem. 146, 246-251.

6. Christopher, J., Pistorius, E., ANd Axelrod, B. (1970) Biochim. Biophys. Acta 198, 12-19.

7. VAN OS, C. P. A., RIJKE-SCHILDER, G. P. M., AND Vliegenthart, J. F. G. (1979) Biochim. Biophys. Acta 575, 479-484.

8. Ramadoss, C. S., PistoriUs, E. K., ANd Axelrod, B. (1978) Arch. Biochem. Biophys. 190, 549-552.

9. YabuUChI, S., Lister, B., AXelrod, B., AND NIELSEN, N. C. (1982) Crop. Sci. 22, 333-337.

10. VernOOY-GerRitsen, M., Veldink, G. A., AND Vliegenthart, J. F. G. (1984) Plant Physiol. $76,1070-1079$.

11. Peterman, T. K., And Siedow, J. N. (1985) Arch. Biochem. Biophys. 238, 476-483.

12. Funk, M. O., CARroll, R. T., Thompson, J. F., AND Dunham, W. R. (1986) Plant Physiol. 82, 11391144.

13. De Groot, J. J. M. C., Veldink, G. A., VlieGENTHART, J. F. G., BoldinGH, J., WEVER, R., and Van Gelder, B. F. (1975) Biochim. Biophys. Acta 377, 71-79.

14. Pistorius, E. K., Axelrod, B., and Palmer, G. (1976) J. Biol. Chem. 251, 7144-7148.

15. Slappendel, S., Veldink, G. A., Vleigenthart, J. F. G., AASA, R., AND MALMSTROM, B. (1983) Biochim. Biophys. Acta 747, 32-36.

16. Cleveland, D. W., Fisher, S. G., Kirschner, M. W., and Laemmli, U. K. (1977) J. Biol. Chem. 252, 1102-1106.

17. LAEMMLI, U. K. (1970) Nature (Lomdon) 227, 680685.

18. Ellman, G. C. (1959) Arch. Biochem. Biophys. 82, 70-77.

19. HAYASHI, R. (1977) in Methods in Enzymology (Hirs, C. H. W., and Timasheff, S. N., Eds.), Vol. 47, pp. 84-93, Academic Press, San Diego.
20. KoOP, D. R., Morgan, E. T., TARR, G. E., AND CoON, M. J. (1982) J. Biol. Chem. 257, 8472-8479.

21. BRAdFord, M. M. (1976) Anal. Biochem. 72, 248454.

22. Funk, M. O., IsAaC, R., AND PoRter, N. A. (1976) lipids 11, 113-117.

23. Keeson, P. H., and Pearlman, N. (1956) in Handbuch der Physik (Fluegge, S., Ed.), Vol. 14, pp. 282-337, Springer-Verlag, Berlin.

24. Feiters, M. C., Veldink, G. A., ANd VliegentharT, J. F. G. (1986) Biochim. Biophys. Acta 870, 367-371.

25. Vliegenthart, J. F. G., and Veldink, G. $\Lambda$. (1982) in Free Radicals in Biology (Pryor, W. A., Ed.), Vol. 5, pp. 29-64, Academic Press, New York.

26. Slappendel, S., Aasa, R., Malmstrom, B. G., VELdINK, G. A., AND VLIEGENTHART, J. F. G. (1982) Biochim. Biophys. Acla 708, 259-265.

27. Feiters, M. C., AASA, R., MALMStrom, B. G., VeLDINK, G. A., AND VLIEGENTHART, J. F. G. (1986) Biochim. Biophys. Acta 873, 182-189.

28. Aasa, R., AND VANngard, T. (1975) J. Magn. Reson. 19, 308-315.

29. Shibata, D., Steczko, J., Dixon, J. E., HermodSON, M., YAZDANPARAST, R., AND AXELROD, B. (1987) J. Biol. Chem. 262, 10080-10085.

30. Shibata, D., Steczko, J., Dixon, J. E., AndRews, P. C., Hermodson, M., AND AXELROD, B. (1988) J. Biol. Chem. 263, 6816-6821.

31. SpaApen, L. J. M., Verhagen, J., Veldink, G. A., and Vliegenthart, J. F. G. (1980) Biochim. Biophys. Acta 618, 153-162.

32. Donovan, J. W. (1969) in Physical Principles and Techniques of Protein Chemistry (Leach, S. J., Fid.), pp. 101-170, Academic Press, New York.

33. Feiters, M. C., Aasa, R., Malmstrom, B. G., Slappendel, S., Veldink, G. A., and VlieGENTHART, J. F. G. (1985) Biochim. Biophys. Acta 831, 302-305.

34. Egmond, M. R., BRunori, M., AND Fasella, P. M. (1976) Eur. J. Biochem. 61, 93-100.

35. Corey, E. J., D'Alarco, M., ANd Matsuda, S. P. T. (1986) Tetrahedrom Lett. 27, 3585-3588.

36. EDELHOCH, H. (1967) Biochemistry 6, 1948-1954.

37. Stevens, F. C., BRown, D. M., AND Smith, E. L. (1970) Arch. Biochem. Biophys. 136, 413-421.

38. Bloom, L. M., BeNkovic, S. J., AND GAFFNEY, B. J. (1986) Biochemistry 25, 4204-4210.

39. YANG, A.-S. AND GAFFNEY, B. J. (1987) Biophys. J. 51, 55-67. 